\title{
The Upper Karabakh Predicament from the UN Resolutions to the Mediated Negotiations: Resolution or Hibernation?
}

\author{
Ali Askerov, $\mathrm{PhD}$ \\ UNCG, abaskaro@uncg.edu \\ Thomas Matyok PhD \\ UNCG, tjmatyok@uncg.edu
}

Abstract

\begin{abstract}
Despite the third party efforts of the significant international and regional organizations, such as the UN and the OSCE, the Upper Karabakh problem remains unresolved for over 20 years. Neither the four resolutions related to Armenia's invasion of Azerbaijani lands adopted by the UN SC in the early 1990s have worked, nor the formal negotiations over this conflict that have taken place under the auspices of the OSCE Minsk Group for more than 20 years have reached any tangible results. These facts give rise to questions about effectiveness of the role of this institution in reaching a resolution to the conflict. The ceasefire regime is in effect since May 1994 without changing the situation, in which Armenia still keeps about 20 percent of Azerbaijani lands under invasion and is effectively involved in building a new state over the invaded lands. This paper analyzes the effectiveness of UN resolutions in liberating Azerbaijan's invaded regions, both within and outside of Upper Karabakh, as well as the OSCE mediation efforts to resolve this conflict. It also discusses effectiveness of the negotiation process, and raises a question about impartiality of the mediators and usefulness of the mediation institution of the OSCE in general. It argues that the OSCE Minsk Group has failed to successfully establish and lead the process of negotiations, thus expecting a fruitful yield is not realistic.
\end{abstract}

Keywords: conflict, Upper Karabakh, UN, OSCE, territorial integrity, mediation, transformation, resolution, management, negotiation

Introduction

The annals of the complex history of the Upper Karabakh region of Azerbaijan are replete with claims to the lands by both Azerbaijanis and Armenians. Fortunately, it is generally accepted that historical accounts have no or trivial value for international law (Shaw, 2003). Nevertheless, the historical annals cannot be underestimated, as they help us understand how the violent protracted conflict between Armenians and Azerbaijanis has developed.

The last cycle of the violence in Upper Karabakh started in 1988, three years before the collapse of the Soviet Union, which developed into a civil war with the Soviet state. A latent conflict for decades, the confrontation in Karabakh took an overt form when the Gorbachev administration failed to calculate the possible consequences of this conflict for the Soviet Union. The Kremlin's initial faltering Karabakh policy shows that Moscow maintained senseless hopes that the conflict would rapidly deescalate from its overt form and return to a dormant state, again. Indeed, Soviet rulers knew that the problem was not new, as Armenians had claimed these lands several times in the past. The latest attempt to wake up the latent conflict was made in August 1987 when the Armenian Academy of Sciences prepared a petition asking for the transfer of the Upper Karabakh and Nakhchivan regions of Azerbaijan to Armenia. The Kremlin's loose approach to the claims contributed to the conflict's move into violence, although the early skirmishes were local and moderately important. Nevertheless, the Kremlin's decision to create a special rule over this region in early 1989 was a critical point in enlarging the conflict, as an emergence of the new legal situation complicated the problem further. At the same time, Armenians perceived the Soviet policy as a green light for them to continue demanding what they sought, the Upper Karabakh region. Later, the process acquired extra complexity in line with enhancing dynamics of the conflict.

Arguably, the Armenians had planed the secession of Upper Karabakh from Azerbaijan long before the conflict initiated publically. Weapons were distributed to Armenian militants in Karabakh as early as 1986 (De Wall, 2003). A few significant events contributed to the escalation of the conflict but arguably nothing had more impact than the expulsion of Azerbaijanis living in Armenia who, at the time, numbered about 300,000. The Azerbaijanis were forced to flee the Armenian Soviet Socialist Republic (SSR) as a result of the growing anti-Azerbaijani sentiments, Armenian mass demonstrations, and Armenian attacks in 1988 (Kruger, 2010). Then, Armenian clearing of Baku and other Azerbaijani towns and villages started and the process ended in 1990. The Kremlin's policies contributed to the rapid escalation of the conflict. In July 1988, Arkadi 
Volsky was named as the representative of the central committee and Supreme Soviet in Upper Karabakh. On January 12 , 1989, Mikhail Gorbachev, the head of the Soviet state, appointed him leader of an eight-member committee of special administration for Upper Karabakh, which had worked against the interests of Azerbaijan. Highly incapable of settling the dispute, Volsky and his team left the region after the massacre in Baku on January 20, 1990. From 1988 to 1991, the clashes in Upper Karabakh between Armenians and Azerbaijanis were local and mostly covert. Soon after the break up of the Soviet Union in late 1991, Armenia and Azerbaijan openly went to war over the Upper Karabakh region of Azerbaijan. Armenia has managed to invade seven surrounding administrative regions of Azerbaijan beyond Upper Karabakh, some of which provided the reason for adoption of the United Nations Security Council (UNSC) resolutions. The UNSC adopted four resolutions on April 30, July 29, October 14, and November 12, 1993 condemning the Armenian invasion of Azerbaijani lands and demanding the withdrawal of Armenian troops from the Azerbaijani regions of Kelbajar, Agdam, Fuzuli, Jabrayil, Qubadli, and Zangilan, all of which are beyond the Upper Karabakh region (Kruger, 2010).

It is quite apparent that Armenia's victory has rested upon Russian support, since Armenia forced the Azerbaijani powers beyond today's borderline with the significant and undeniable help of Russia. From the very beginning of the violent confrontation, Russia supplied Armenia, at a minimum, with arms and fuel. The participation of Russia's 366th motorized infantry regiment, supporting the Armenian side in the Khodjaly massacre on February 25, 1992 and killing hundreds of Azerbaijani civilians, was apparent and well documented (Goltz, 1998). Highlighting Russia's role in the creation and development of this conflict is important for making an argument that, once openly and then covertly, Russia has been an active participant to this conflict. At the same time, Russia has been a co-chair of the mediating Minsk Group of the OSCE since its inception. Obviously, this is very a paradoxical situation.

\section{From Covert Conflict to Overt War}

The Upper Karabakh conflict has been a covert one for decades; certainly, throughout the period of Soviet rule. Armenian claims to Upper Karabakh go back to the early years of the Soviet Union and even beyond (Cornell, 1997; 1999). Armenians unsuccessfully demanded the region from Azerbaijan during the time of Nariman Narimanov's in the 1920s, Mir-Jafar Bagirov's period in the 1930s, and into the 1960s. The conflict re-emerged on an overt scale in August 1987 when the Armenian Academy of Sciences demanded the transfer of the Upper Karabakh and Nakhchivan regions of Azerbaijan to Armenia. The Kremlin's loose approach to the claims made the conflict rapidly grew into violence, although skirmishes remained local and were of moderate importance. Nevertheless, the Kremlin's decision to create a special administrative rule over the region in early 1989 was a critical point in enlarging the conflict, as an emergence of the new legal situation further complicated the problem. At the same time, Armenians perceived this as a green light for them to continue demanding what they sought. Later, the process acquired extra complexity in line with enhancing dynamics of the conflict.

The special rule of Upper Karabakh was Moscow's project eschewing the interests of Baku because the plan sought to secede it from Azerbaijan. However, the dynamics of the conflict and overall political developments in the Soviet Union did not let it happen. Lately, select Russian politicians have argued for, if not suggested the need to invade, Upper Karabakh as part of Russia, eschewing the claims of both Azerbaijan and Armenia (Yeni Musavat, 2014, April 1). During the period of the special rule in Upper Karabakh, Moscow let Armenia build the necessary base for further fight against Azerbaijan while weakening the position of the latter. The conflict's long and complex history does not necessarily mean that its transformation is impossible. Today, however, the resolution approach to this conflict is not promising for a number of reasons discussed below.

\section{Parties to Conflict}

Today, after twenty-seven years, still one of the most important problems related to this conflict is the disagreement about who the parties to the conflict are, and who should negotiate in assisting to remove the differences. It is assumed that the conflict is international, the parties to the conflict are Armenia and Azerbaijan, and that conflict resolution processes in the form of talks have been taking place between these two states. However, officially, Armenia denies being a party to the conflict (Kruger, 2010). Armenia claims that the sides to the war are Azerbaijan and the Upper Karabakh Armenians. Needless to say, negotiating a conflict without clearly determining who the sides to it are is eccentric, at best. Obviously, not only is the capacity of Armenia as a negotiator questionable, also the situation seems to be a strange one when it comes to raising questions of trust. The situation itself, coupled to an odd conflict transformation scheme, has the potential to raise doubts at different phases of the negotiation process. 
Indeed, Azerbaijan does not recognize the Karabakh Armenians as a party to the conflict objecting to their direct participation in any negotiations. The current status of the region is explained by the manifestation of military power of Armenia and Russia, rather than the Armenians of Upper Karabakh. Hence, making the local Armenians a party to the talks is another form of trying to impose force on Azerbaijan. Although Armenia's attempt to justify its violent presence in Azerbaijani lands through making the Karabakh Armenians a party to the negotiations has not been successful, this issue has raised doubts about the effectiveness of the negotiations process.

\section{A Civil or International War?}

With the collapse of the Soviet Union in late 1991, the war of Karabakh acquired an international character. The new situation had created a fertile ground for the Russian troops present in the region to help Armenian paramilitaries advance into Azerbaijan's other regions, eventually invading seven administrative districts of the country, in addition to the entire Upper Karabakh region. It is important to stress that Russian military support played a crucial role in Armenian military success. Even the Khodjaly massacre of February 1992 was executed by the joint Armenian and Russian troops. As aforementioned, the UNSC adopted four resolutions regarding Armenia's aggression in Azerbaijan.

The UNSC resolution 822 adopted on April 30, 1993, called for the cessation of hostilities and withdrawal of Armenian forces from Kelbajar district of Azerbaijan following its occupation on April 3, 1993. The UNSC resolution 853 adopted on July 29, 1993 demanded the immediate cessation of all hostilities and called for the withdrawal of local Armenian troops from the Agdam district of Azerbaijan occupied on June 23, 1993 and reaffirmed UN Resolution 822. The UNSC resolution 874 was adopted on October 14, 1993. The UNSC resolution was adopted on November 12, 1993 condemning the violations of the cease-fire established between the parties. The resolution called upon the government of Armenia to use its influence to achieve compliance by the Armenians of Upper Karabakh with resolutions 822, 853 and 874. It also called for the withdrawal of local Armenian troops from district of Zangilan and reaffirmed UN Resolutions 822, 853, 874.

Nonetheless, the resolutions were never enforced having nothing more than an effect of recommendations. The resolutions, indeed, did not address the question correctly, since they did not assertively stress the element of international aggression. They have eventually displayed double standards existing in the UN system. At a historical moment, the UN threw the ball to the Organization for Security and Cooperation in Europe (OSCE), which created the Minsk Group to handle the Upper Karabakh issue. Unfortunately, the co-chairs of the Minsk Group, which are Russia, France, and the US, have not been able to create a trustworthy working environment to handle the issue effectively. The result is that the conflict has been in latency up until today, despite the frequent breaches of ceasefires and the numerous victims on both the sides. It is likely that the peace process will yield no fruit under the auspices of the Minsk Group of the OSCE. The official Baku has repeatedly expressed its scepticism in any positive outcomes as a result of the role played by the Minsk Group (Askerov, $2014 ; 2015)$. The discontent of the victim may seriously contribute to the waking the latent conflict up at any time initiating a new phase of escalation.

\section{Uselessness of the UN and Its Resolutions}

Recently, some officials on the Azerbaijani side have expressed wishes to return back to the UN as a facilitating institution. As mentioned above, the UNSC adopted four resolutions regarding Armenia's aggression against Azerbaijan in 1993. However, the fact that none of these resolutions has been implemented in any form raises a question about the mission of this institution in general, and its effectiveness in this particular case. It is true that none of these resolutions was adopted under Chapter 7 of the Charter, however the strong and decisive language used to construct the document reflected the solid approach of the organization to this conflict. It is quite interesting that the most influential organization in the world, the UN, recommended ceasing the war and initiating negotiation of the differences. Nevertheless, this particular approach cannot be assessed as productive, at least because in the give-and-take process Azerbaijan's position is asymmetrical. Creating a fair environment for both the parties before starting negotiations requires an equitable approach that has never taken place.

Perhaps, this reveals the problems associated with the malfunctioning of the UN system. The recent increase of the number of voices against the working procedure and structure of the UN system is not baseless. President Tayyip Erdogan of Turkey, one of the most outspoken challengers of the UN, often criticizes the UN system and its policies. Recently, in his speech at the UN General Assembly, he had said the world was bigger than five, the number that denotes the permanent 
members of the Security Council, and claimed that the UN needed a new and functioning decision-making mechanism (Erdogan, 2015). Certainly, Erdogan is not the only unhappy leader who criticizes the UN system. But the truth is that the UN applies double standards to separate but similar cases. Those who hope that taking the Upper Karabakh case back to the auspices of the UN need to take this point into consideration. The fact that the OSCE is ineffective in the transformation of the Upper Karabakh conflict does not add to the success of the UN as a mediating institution.

\section{Early Mediation Efforts and the Ceasefire Agreement}

No direct negotiations have taken place between Armenia and Azerbaijan. A third party has mediated all negotiations that have occurred between these parties. Early mediation efforts were not structured successfully to bring about well-organized talks. The first attempt at mediation took place in September of 1991, a couple of months before the collapse of the Soviet Union. The initiators were Boris Yeltsin and Nursultan Nazarbayev who came to the conflict affected region to arrive at a ceasefire agreement between the sides. However, with the collapse of the Soviet Union they ended their mission.

Iranian mediation took place from February 1992 to May 1992. As a neighboring state to both Azerbaijan and Armenia, Iran made an attempt to bring the parties to the negotiation table to find a solution to the problem through mediated talks. However, while talks were taking place, Armenia tricked both Iran and Azerbaijan invading Shusha, the most important city for Azerbaijan in the region. Iran's mediation collapsed due to Armenia's increasing aggression and the power vacuum in Azerbaijan.

In August 1992, Nursultan Nazarbayev, now president of independent Kazakhstan, took another initiative to mediate between the parties, but the sides did not respect his efforts leading to the collapse of his mediation. Following a number of fruitless attempts, the sides reached a ceasefire agreement in May 1994, after which the mediation of the CSCE (later OSCE) became dominant. Some scholars (Mooradiand \& Druckman, 1999) explain the importance of the ceasefire and negotiations using ripeness theory, which states that when parties do not see a likelihood of victory, and they have drained their resources, they have strong motivations to negotiate or to seek mediation. This argument is hardly true for the Upper Karabakh case, at least because when the mediated negotiations started between the parties, Armenia had already reached its objectives of invading the Upper Karabakh region and much beyond. Moreover, accurately measuring tangible and intangible resources of the parties of the time is practically impossible, thus claims about exhausting resources are not sound.

\section{The Minsk Group}

The Minsk Group of the OSCE has been the only mediator since January 1995. By means of its mediation, the presidents of Armenia and Azerbaijan have met numerous times. However, The OSCE mediation has not contributed to any concrete progress. The OCSE has been nothing more than an ineffective conversational forum for the parties to the conflict and the co-chairs of the Minsk Group.

In theory, the task of mediation aims at bringing the sides to a conflict together to negotiate their differences and to reach a desired outcome. However, the desired outcome is not the same for both parties. The parties to this conflict have not been willing to give up their desires, even partially, on behalf of the other party. A legitimate question to ask is related to what has been done to achieve which goal over the issue of the Upper Karabakh problem?

In 1993, Azerbaijan could deal with its own issue of Karabakh had the Russians not assisted the Armenian-Kharabakh troops with weapons, ammo, fuel, and expertise. Thus, to win, or at least to be better positioned for the post-war settlement, Baku needed to persuade Moscow to quit supporting the Armenians (Tchantouridze, 2008). This never happened because of Armenia's geopolitical importance to the Kremlin. Russia's pro-Armenian policy, and its identity as a co-chair of the Minsk Group that requires impartiality, contradict each other.

It is hard to call the ceasefire, which is in effect since May 1994, successful, since soldiers, even civilians, are killed on each side on a regular basis (Herszenhorn, 2015). Moreover, ceasefire is a situation that connotes a state of peace that is reached to stop violence. Therefore, a ceasefire is a form of negative peace, a situation where violence is absent with persisting problem, and may return to direct violence again. After a two-decade long charge, the only tangible success of the Minsk Group is the organizing of meetings of the presidents of Azerbaijan and Armenia (Askerov, 2014). 


\section{Some Principal Concepts and Statements of Peace}

Let's consider some relevant concepts of peace and certain statements related to the situation in the region. Perhaps, the most frequently used phrase about the war of Karabakh is associated with peaceful resolution of this conflict. Especially, the third parties recurrently use peace rhetoric stressing that the only way of resolving this crisis is a peaceful one (Bordyuja, 2005). This approach opts out of the utilization of the institution of war as an alternative means to handle this conflict. Regrettably, in reality it does not work as easily as it is pronounced. The Upper Karabakh conflict has a violent character and therefore it is identified and called a war. Opting out of war as an institution to be used to conclude the confrontation as a phenomenon is not realistic, nor is bias free. The status quo in the war region is in Armenia's favour, because it has reached all its objectives formulated before the struggle started, and even moved far beyond them. Before the war began, Armenia wanted the Upper Karabakh region of Azerbaijan, which is about 4,400 sq. km, but now it additionally controls 7,634 sq. $\mathrm{km}$ lands of Azerbaijan. After reaching this extreme point by means of bloody fighting, stopping the war is in Armenia's interests because the status quo gives it a chance to keep and manage the situation as long as possible. In this sense, the policy of the Minsk Group of the OSCE to preserve the no war- no peace situation has tremendously supported Armenia's position. This is one of the main reasons of Armenia's and its supporters' frequent declarations about the peaceful resolution of the conflict as the single and exclusive option. Although this approach is not realistic and war as an institution still occupies an important place in international relations, it becomes important to clarify the conceptual framework of the peace process to evaluate its proposed effectiveness.

Conflict resolution, conflict transformation, and conflict management are the three key terms associated with many violent and nonviolent conflicts and they are often used interchangeably. However, they have quite different meanings. Conflict management refers to the practice of identifying and handling conflicts sensibly, fairly, and efficiently through diminishing the negative aspects of conflict while increasing its positive sides. Obviously, this is not the case in the Upper Karabakh conflict because it is all about managing the situation through preserving the existing negative peace that refers to the absence of violence (Galtung, 1996). This "absence of violence" is also a relative notion. The frequent violation of the ceasefire agreement in the region shows that violence is not completely absent. Also, the existing overall situation in the region, which is a product of the war, has been brutal to people fleeing their homes for over two decades. However, it can well be called situation management, as it preserves the existing situation associated with the state of Armenia's invasion.

As a process, conflict resolution also aims at bringing about peace but in this case, it means more about trying to eliminate conflict without thinking about future positive change as an aspect of the process (Lederach, 2003). In this case, the involved third parties are not interested in bringing justice to the region; rather they are working for a violence-free region. Trying to end this conflict in its existing form is trying to cover up the manifold problems Azerbaijan has faced due to the war.

One of the best ways of handling conflicts is using the model of conflict transformation, which has a capacity to offer constructive change that may include, and even go beyond, the resolution of specific problems (Lederach, 2003). Conflict transformation as a dynamic process offers an opportunity to see peace as a continuously evolving and developing quality of relationship. A close analysis of the peace process reveals that over the past 20 years no conflict transformation activities have taken place in Upper Karabakh; rather, serious efforts have been made to keep the status quo achieving stalemate in the region.

\section{Goals and Objectives of the Sides}

Parties always have their own objectives, and to reach them they design respective policies and mobilize all the means available to achieve them. Azerbaijan's policy is based mainly on the norms of international law such as territorial integrity, and the most powerful weapon the Azerbaijani government employs is the four aforementioned resolutions of the UN Security Council adopted in the early 1990s in connection with Armenia's invasion of Azerbaijani administrative regions Kalbajar, Aghdam, Zengilan, Jabrayil, Fuzuli, and Lachin. Although more than 20 years have passed since the invasion of these administrative areas of Azerbaijan with about a million of internally displaced people, no positive change has taken place to spark the hopes of these people ever returning to their homes.

One of the Armenia's objectives is reaching the complete secession of Upper Karabakh and part of Lachin from Azerbaijan. Today, all the goals of Armenia have de-facto been satisfied. In addition to Upper Karabakh, Armenia controls the lands of Azerbaijan almost three times larger than the former autonomous republic. Today, the legal status of Upper Karabakh remains as the only problem for Armenia. 
Obviously, the objectives of the parties are two opposite extremes, and the farther the aims, the harder to reach the agreement. In this situation, expecting direct negotiations from the sides to the conflict is futile. Bringing the parties together for talks requires an effective third party role, and the co-chairs, one of which is Russia, assume this role.

\section{Clashing Priorities}

Azerbaijan's priority is preserving its territorial integrity. Within its territorial integrity, Azerbaijan is ready to grant the Upper Karabakh region any status without changing its own unitary administrative structure. In other words, Azerbaijan would accept no federation or confederation with the Upper Karabakh Armenians. Armenia's priority, however, is reaching the objective of a new statehood for the Armenians of Karabakh. Yerevan has placed its policy on the principle of selfdetermination, which is part of international morality, while forcing last three hundred thousand ethnic Azerbaijanis leave Armenia. Apparently, this constitutes an ethical dilemma with the Armenian demands.

Unlike Armenia, Azerbaijan uses the well-established rules of international law such as national unity, territorial integrity, and the principle of non-interference. Nonetheless, these rules appear to be ineffective in changing the situation in a positive way. Perhaps the new international circumstances are not ripe enough to assert that these rules are obsolete, and there are needs for a reform in this realm. The undeniable fact, however, is that the priorities of Azerbaijan and Armenia clash thus increasing the complexity of the conflict.

\section{Persuasion}

Is power more important than morality? Paradoxically, it is Armenia that used power to invade Azerbaijani lands, and it is the same Armenia that tries to justify its position with the principle of morality. The use of force can be justified for selfdefence only. Azerbaijan has full rights to free its lands and defend its citizens. It would be just and ethical. Certainly, violent conflicts can also be resolved through negotiations, and the Upper Karabakh conflict is tractable provided that the institution of mediation works properly, and the rules and principles are used without any double standards. Subsequently, the elements of trust and persuasion should come into play as well. Today, neither the mediators can persuade both parties about the effectiveness of the negotiation process, nor the parties to the conflict can assure each other about the usefulness of their packages. Simply, trust does not exist.

\section{Russia's Role in the Mediation}

Russia's military presence in Armenia and its geostrategic interests in the region poses a question about its impartiality as a mediator. As aforementioned, the Upper Karabakh region of Azerbaijan was not invaded by the armed forces of Armenia alone. Russia has given full military support to Armenia and the Armenians of the Upper Karabakh region to defeat Azerbaijan. Russia's support started three years before the collapse of the Soviet Union and still continues. Russia and Armenia are strategic allies, and Russia's troops are stationed in Armenia. Moreover, Russia has long tried to impose the Upper Karabakh Armenians as a party to the conflict (Yeni Musavat, 2014, March 24). Experts argue that withdrawal of Russia's military and other support from Upper Karabakh would enable Azerbaijan to easily restore order in the region in a way it wishes (Ses Qezeti, 2015). This argument is not made to underestimate Armenian power or overestimate Azerbaijan's strengths, rather it is made to show Russia's role in the region. Moscow's policy towards the Southern Caucasus reflects its interests in the region. Russia is interested in keeping the whole region under its influence, and this entails keeping the conflict unresolved.

Besides, Russia has a number of severe problems with Azerbaijan. Perhaps, the most important difference between them, even more significant than supplying weapons to Armenia, is over the status of the Caspian Sea. But, in general, Moscow likes to demonstrate its power to the former Soviet republics to influence them. The recent events in Crimea and Donetsk regions of Ukraine are good examples for Russia's antagonistic policies towards its neighbours (Askerov \& Matyok, 2015). Moscow has tested the West in Ukraine, and now it knows that restoring its former sphere of influence is quite possible. Azerbaijan is one of its targets primarily because of its energy potentials, among other things. The West needs Azerbaijan's energy, and Russia will try to cut it off. Moscow will continue using the Karabakh card effectively to this end. In this case, Russia's impartiality in the Armenian and Azerbaijani conflict is impossible, and, hence, Russia's mediating role in the Karabakh conflict is a sham and ineffective. Let's discuss this further below. 


\section{Resolution or Hibernation?}

As noted above, negotiating this conflict through the mediation of the co-chairs of the Minsk Group has taken over two decades. This, perhaps, is one of the longest negotiating processes in the world over any similar protracted violent conflict. It wouldn't be too cynical to claim that the Minsk Group of the OSCE is more interested in managing the conflict, not allowing it to turn into wide-scale armed hostilities, rather than trying to help find a more permanent solution satisfying the needs of both the parties. It is hardly possible to evaluate this as a sample of positive conflict management, rather it looks like a conflict drawn out with negative consequences.

It is important to stress the significance of the identity of the co-chairs of the Minsk Group. One of the golden rules of the success for mediation is the impartiality of the mediators. We have discussed Russia's role above and questioned its impartiality. Let's consider it further through some points related to our case.

The three co-chairs of the Minsk Group of the OSCE are the US, France, and Russia. The co-chairmanship of the first two is acceptable to both parties, despite some instances, in which one of the parties may object to a particular situation. For instance, recently the American co-chair James Worlikin talked about the so-called Nagorno-Karabakh Republic as a side to the conflict (Yeni Musavat, 2014, March 24). This has long been Armenia's Moscow-backed policy, and Azerbaijan has always rejected this approach. The newly appointed US co-chair makes a statement in line with Russia's and Armenia's policies raising new questions about the impartiality of the mediators. Otherwise, Worlikin's knowledge about the political situation in the region and the mediation process is insufficient, and this hurts the sense of seriousness about the conflict transformation process related to the problem. Ironically, Ambassador Joseph A. Presel, the former US co-chair of the Minsk Group and special negotiator for Upper Karabakh in 1995, has recently noted that the situation around the issue is just the same as it was twenty years before (Musavat, 2015). The third party involvement has not contributed to the resolution of the conflict positively. The only visible effect of the mediation institution is that the Upper Karabakh conflict has remained in the state of dormancy over the past two decades despite the frequent breaches of the ceasefire.

\section{Threat of Withdrawal}

Azerbaijan has repeatedly stated that it has lost hopes for a radical change in this conflict by means of negotiations. President Aliyev and other high-ranking officials of Azerbaijan have made many statements that, if necessary, Azerbaijan would use force to restore peace and justice in Karabakh (APA News, 2014, March 19; Azernews, 2013, October 29; Trend, 2013, October 28; Rajabova, 2013, August 26). Likewise, President Sarkissian of Armenia has occasionally threatened Azerbaijan with the use of force, in the case of Azerbaijan's attack. In reality, the limited use of force has never stopped in the region. Both sides have faced casualties due to adversarial sniper shootings.

Unlike Armenia, on a number of occasions, Azerbaijan has directly or indirectly threatened to withdraw from the negotiations. Ostensibly, Azerbaijan is unhappy with the status quo, and the ongoing process of negotiations. Being a victim country with its lands invaded, Azerbaijan sees itself in a position of imposing pressure on the co-chairs of the Minsk Group. The existing situation is in favour of Armenia, which uses the process effectively to maintain the stalemate. This, however, does not mean that Armenia is against war, since its relations with Russia creates certainty of Russia's military support in case of a renewal of the war.

Azerbaijan's position can be interpreted as a manifestation of a protest to injustice and indifference of the world community to its problems that emerged as a result of Armenian aggression. However, in these historical circumstances, trying to reestablish justice by means of war may not be in the interest of Azerbaijan. Analysts argue that Russia is pursuing a plan to enter Azerbaijan, and one of the best ways of accomplishing such an objective is a renewal of the war in Karabakh (Residoglu, 2014).

\section{Then Why Do Negotiations Still Take Place?}

Evidence for principled-negotiations to satisfy the needs of both parties does not exist. In a number of occasions, both parties have repeatedly used rhetoric of total victory displaying a hard stance and no willingness for developing empathy for the other's needs. The pessimistic approach to peace is a manifestation of the impasses in the negotiations. In this case, the legitimate question to ask is why negotiations still take place? Certainly, there are many reasons for this, however, 
it seems the most logical answer to this query is that the sides to the conflict have secret agendas, which are mainly related to winning time. This point may sound too simplistic when we talk about a century-long protracted violent conflict, the parties to which are struggling to resolve their differences through 20-year long negotiations without giving major concessions. Let's consider the situation concerning both republics.

Baku was initially concerned with developing possible models to extend the profits of both parties. The models that were publicized in the mid-1990s revealed Azerbaijan's willingness to step-by-step resolution of the conflict and granting Upper Karabakh the highest autonomy that exists in the world without damaging its own territorial integrity. This approach has been a more constructive attitude than that of Armenia's offering a strong possibility to construct a win-win situation. No state would be willing to lose any part of its territory, and sometimes it is necessary to present something very exquisite not to let the processes develop to that point. In conflict transformation we seek an elegant response. Azerbaijan's offer to that end can be interpreted as satisfying its own interests to the greatest extent by offering the Armenians of Upper Karabakh a much higher autonomy than they enjoyed during the Soviet times. However, today no signs about the validity of this initial proposal exist. Rather, war rhetoric has replaced the previous constructive speeches of the Azerbaijani political leadership (Askerov, 2014).

Armenia, as of today, is a winning party, and therefore it states its position in explicit terms trying to maximize its own gains. It demands one of three: independence to Upper Karabakh, its unification with Armenia, or its confederation (or lose federation) with Azerbaijan. If the conflict remains frozen, the status quo in the region would make Armenia's aspirations totally satisfied. The fact that Armenia exercises effective control over the occupied Azerbaijani lands outside of the Upper Karabakh region makes Yerevan exceptionally powerful in not displaying any concessions to Baku except for returning those invaded non-Karabakh lands back to Azerbaijan in exchange of the entire Upper Karabakh region in addition to a corridor through Lachin district of Azerbaijan. Armenia's unwillingness to give concessions to Azerbaijan is sufficient to create an impasse in the negotiation process.

Besides, it must be noted that no significant preparation of the publics in both Armenia and Azerbaijan for possible concessions have taken place. This is a sign of the absence of any agreement over an acceptable model for the resolution or transformation of the conflict.

\section{Discussions and Conclusion}

The frequent rhetoric about the Karabakh war sounds that war is not a solution to this problem, which is created through war and violence. Although Azerbaijan, as a victim of foreign aggression, has a moral right to use war as a means to restore its territorial integrity and re-establish peace and justice in the region, it has preferred a peaceful resolution of the conflict. However, the mediation institution in the peace process is not productive; at least because one of the mediators, Russia, is a party to the conflict and others, France and the US, have large Armenian diasporas that influence the process. It is hard to make a claim that the third parties involved in the peace process are contributing to the development of a positive peace that could endure in the region for a long time. Rather, it is obvious that they are trying to impose peace on Azerbaijan without significantly changing the existing situation. The negative nature of the imposed peace may become a driving force for conflict eruption at any time in the future.

Azerbaijan's lands have not been occupied by Armenia alone and without a foreign help; rather it has been supported by Russian troops significantly. Even today, Russia and Armenia are parties to the serious bilateral agreements on security issues that are primarily against Azerbaijan, since Armenia has an armed dispute only with this country. It is an undeniable fact that Russia has been a party to the Upper Karabakh war since its commencement. Due to the current latent form of the war, however, Russia's presence in the conflict is not visible. One and the same actor cannot play two separate and contradictory roles regarding the same issue. Russia's partiality is unethical disqualifying it as a mediator between Armenia and Azerbaijan. On the other hand, settling the problem over Upper Karabakh is not part of Russia's policy, since this would weaken the Kremlin's position in the region. It is also not a surprise that Russia not only nurtures Armenia with weapons but it also sells arms to Azerbaijan.

Arguably, international and regional organizations do not exist to restore justice in the world. In fact, it is not among their tasks to evaluate what justice is. Rather, they are interested in preventing violence and keeping peace, which can hardly be classified as positive. Negative peace, however, might always potentially generate a new waive of violence, which is associated with war that can be just and unjust. By waging unjust war, Armenia has invaded Azerbaijan's lands. Since 
Armenia did not get Azerbaijani lands by peaceful means, a question arises about why Azerbaijan is expected to restore its territorial integrity exclusively by peaceful means? Pacific means have been attempted for about 21 years without any success due to the co-chairs' implicit consent to the existence and endurance of the current status quo in the region. This connotes to more to ignoring peace than making it. Under these circumstances, Azerbaijan, the victim of the conflict, has legal and ethical rights to restore its unity and prestige through fighting if no other method works within a short period of time.

The mediation efforts of the third party, the Minsk Group of the OSCE, are quite active but fruitless. High-level meetings between the leaders of the two republics have taken over 300 times, the problem, however, has not been taken forward even an inch. Azerbaijan's political leadership has repeatedly announced that the government of Azerbaijan still hopes for peaceful resolution of the conflict. However, in a number of different occasions, the president of Azerbaijan announced that Azerbaijan might use the institution of war as the last resort to free its invaded lands to establish peace and justice in its own lands.

As this paper argues, both the official Baku and opposition leadership of Azerbaijan do not believe in any possible breakthrough of the conflict with the help of the Minsk Group. Evidence shows that both the government and opposition leaderships of Azerbaijan are more willing to take the problem into the agenda of the UN having the third party efforts removed from the OSCE. More importantly, the Azerbaijani political leadership believes that enforcing the aforementioned resolutions of the UNSC is the most viable potential resolution of the conflict apart from active military operations as a last step. As the paper further argues, the course of the negotiations over Upper Karabakh is in line with the aspirations of Armenia, which is interested in keeping the current status quo in the region by dragging the process as long as possible to win time. Arguably, the negative peace in Upper Karabakh may not last forever and violent conflict may erupt anytime bringing about detrimental consequences for the entire region.

Over twenty years have passed since the negotiations started between Armenia and Azerbaijan, however still the issue of conflict parties is vague. The co-chairs occasionally make grave mistakes displaying their insufficient knowledge about the issue, process, and policies of the conflict parties. Arguably, the co-chairs are more interested in managing the conflict situation not to allow the outbreak of the war than trying to create new grounds for its transformation. Obviously, the mediation institution does not work efficiently.

Ostensibly, Russia's impartiality is profoundly questionable. Russia has contributed to the creation of this conflict tremendously and sustained it for its own geostrategic purposes. No evidence exists to claim that Russia has played an important role in the efforts of transforming this conflict. In fact, one of the gravest problems throughout the process of negotiations has been Moscow's practise of a double standard. If Russia does not change its policy towards the region positioning itself at equidistance from Armenia and Azerbaijan, distrust of Baku towards Moscow will not be neutralized. In that case, continuing with the negotiation process with the traditions of the Minsk Group will not yield any positive result unless the membership and policy of the Minsk Group change.

\section{References:}

[1] APA News. Ilham Aliyev: Azerbaijan Will Restore Its Territorial Integrity and Sovereignty. March 19, 2014

[2] Askerov, A. (2015). The UN, OSCE, and Azerbaijan's Karabakh Impasse: Imposing or Making Peace? In The Actual Problems of Azerbaijani Studies. Slavyan University, Baku, Azerbaijan.

[3] Askerov, A. (2014). The Mountainous-Karabakh Conflict: Negotiating for Peace or Winning Time? Globallasma Prosessinde Qafqaz ve Merkezi Asiya, Economics and International Relations IV International Conference, Qafaqz University, Baku, Azerbaijan.

[4] Askerov, A. \& T. Matyok. Power, National Unity, and Territorial Integrity: The Cases of Russia's Chechnya and Ukraine's Crimea, Europea Journal of Interdisciplinary Studies, Vol. 1, No 1, April 2015.

[5] Azernews. Deputy PM: Azerbaijan to liberate its occupied lands by any means. October 29, 2013

[6] Bolukbasi, S. (2011). Azerbaijan: A Political History. London: I.B. Tauris 
[7] Bordjuja: ODKB ne budet voevat s Azerbaydjanom iz-za Karabakha (Bordyuzha: CSTO will not fight against Azerbaijan because of Karabakh) Yeni Musavat, January 31, 2015

[8] Cornell, S. E. The Nagorno Karabakh Conflict, Report no. 46, Department of East European Studies, Uppsala University, p. 1-164, 1999

[9] Cornell, S. E. Undeclared War: The Nagorno-Karabakh Conflict Reconsidered, Journal of South Asian and Middle Eastern Studies, Vol. 20, No.4, p. 1-24, 1997

[10] De Waal, T. (2003). Black Garden. New York University Press

[11] Erdoğan: Dünya 5'ten büyüktür (Erdogan: the World is Bigger than 5). Al JazeeraTürk, Sept. 24, 2014. http://www.aljazeera.com.tr/haber/erdogan-dunya-5ten-buyuktur (Accessed February 5, 2015)

[12] Galtung, J. (1996). Peace by Peaceful Means: Peace and Conflict, Development and Civilization. SAGE Publications.

[13] Goltz, T. (1998). Azerbaijan Diary: a rogue reporter's adventures in an oil-rich, war-torn, post Soviet republic, p. 140, M.E. Sharpe, New York.

[14] Herszenhorn D. M. Clashes Intensify Between Armenia and Azerbaijan Over Disputed Land. The New York Times, Jan. 31, 2015

[15] Kruger. H. (2010). The Nagorno Karabakh Conflict, A Legal Analysis. Springer-Verlag Berlin Heidelberg

[16] Lederach, J. P. (2003). The Little Book of Conflict Transformation. PA: Good Books.

[17] Mooradian, M. \& D. Druckman. Hurting Stalemate or Mediation? The Conflict over Nagorno Karabakh, 1990-95, Journal of Peace Research vol. 36, no. 6, p. 709-727, 1999

[18] Rajabova, S. (2013) Azerbaijan warns will use its army if Armenian aggression continues. Azernews, August 26,2013

[19] Residoglu, A. Naxcivani Kim Xilas Etdi? (Who Saved Nakhchivan?). Yeni Musavat, April 9, 2014.

[20] Ses Qezeti. Qabil Huseynli: "Ermenistani sixib, suyunu cixarmaq olardi" (Qabil Huseynli: "It would be possible to squeeze Armenia to its juice") January 29, 2015

[21] Shaw, M. N. (2003). International Law. Fifth Edition. Cambridge University Press

[22] Tchantouridze, L. The Three Colors of War: Russian, Turkish, and Iranian Military Threat to the South Caucasus, Caucasian Review of International Affairs. Vol. 2 (1) - Winter 2008

[23] Trend. Minister: Azerbaijan reserves right to liberate its occupied lands. October 28, 2013.

[24] Yeni Musavat. Abbas Abbasov Jirinovskiden Rusiyanin Bas Prokuroruna Sikayet etdi (Abbas Abbasov complained to Russia's Chief Prosecutor about Jirinovsky). April 1, 2014

[25] Yeni Musavat. Vefa Qulizade: Amerikali Hemsedr Qovulmalidir (Vefa Quluzade: The American Chair should be Kicked Out). March 24, 2014

[26] Yeni Musavat. Amerikali Kecmis Hemsedr: "Qarabag Meselesi 20 II Once Harada Idise, Indi de Oradadir" (Former American Co-chair: "The Karabakh Issue Has Not Changed Over the Past 20 Years"). June 15, 2015 